\title{
SOCIOEKONOMSKI RAZVOJ I KVALITETA ŽIVLJENJA U SJEVEROZAPADNOJ HRVATSKOJ: STATISTIČKA REGIONALIZACIJA KAO OKVIR ZA ELASTIČNU POD-REGIJU
}

\begin{abstract}
Kvaliteta življenja u sjeverozapadnoj Hrvatskoj je nedvojbeno povezana s iznadprosječnom regionalnom konkurentnošću. Konkurentnost, pak, izvire iz djelovanja jednog ili više proizvodnih "clustera". No, europska statistička regionalizacija mijenja okvire tradicionalne regionalne podjele Republike Hrvatske. S druge strane, županijska administrationa organizacija zemlje ne može odgovoriti zahtjevima NUTS 2 razine europske statističke regionalizacije. Zbog toga u Hrvatskoj trenutno postoje samo dvije statističke regije. Postojanje višse homogenih "clustera" na području sjeverozapadne Hrvatske sugerira potrebu da se ovaj prostor, $u$ uvjetima europske statističke regionalizacije, promatra kao elastična pod-regija.
\end{abstract}

\section{UVOD}

U ovom će se radu raspravljati o razvojnim perspektivama prostora sjeverozapadne Hrvatske u uvjetima županijskog administrativnog ustroja zemlje te u uvjetima europske teritorijalne statističke organizacije (NUTS). ${ }^{1}$ Poznato je, naime, da se u uvjetima europske regionalizacije nacionalni teritoriji promatraju kroz tri različite

\footnotetext{
Nomenklatura prostornih jedinica za statistiku je hrvatski prijevod francuskih termina Nomenclature des Unités Territoriales Statistiques koje predstavljaju hijerarhijski sustav klasifikacije teritorija EU unutar nacionalnih, regionalnih $\mathrm{i} / \mathrm{ili}$ administrativnih granica zemlje. Koristi se za potrebe regionalne statistike unutar EU. Sustav se sastoji od pet razina NUTS 1, NUTS 2 I NUTS 3 te još dvije dodatne razine LAU 1 I LAU2 koje se odnose na lokalne administrativne cjeline, u hrvatskom slučaju na općine i gradove. U skladu s tim sustavom Hrvatska predstavlja NUTS 1 razinu, Kontinentalna i Jadranska Hrvatska NUTS 2 razinu a županije NUTS 3 razinu.
} 
statističke razine poznate kao NUTS 1, NUTS 2 i NUTS 3 od kojih dvije (NUTS 2 i NUTS 3) nisu utemeljene na povijesnim hrvatskih regijama. ${ }^{2}$ Stoga je svrha rada objasniti socio-okolišni položaj ${ }^{3}$ sjeverozapadne Hrvatske u okviru europske statističke regionalizacije ${ }^{4}$ i u uvjetima županijskog administrativnog ustroja zemlje. ${ }^{5}$ Cilj je, pak, ovog rada rasvijetliti razvojne mogućnosti koje bi inovativno organiziranje teritorija koje uvažava europsku statističku organizaciju NUTS 1, NUTS 2 i NUTS 3 moglo proizvesti na prostoru sjeverozapadne Hrvatske. U skladu s navedenom svrhom i ciljem u radu će se prvo objasniti konceptualni okvir za analizu koji će biti popraćen pregledom relevantne literature a zatim će se raspravljati o prijeporima vezanim za županijsku upravnu organizaciju nacionalnog teritorija i regionalizaciju u okviru odredbi Zakona o regionalnom razvoju. ${ }^{6} \mathrm{Na}$ kraju će se objasniti koncept elastične pod-regije kao okvir za sustavni razvoj sjeverozapadne Hrvatske u volatilnim administrativnim uvjetima. $^{7}$

\section{KONCEPTUALNI OKVIR ANALIZE I PREGLED RELEVANTNE LITERATURE}

Sjeverozapadna Hrvatska promatra se u ovom radu kao zavičajna cjelina ${ }^{8}$ koju konstituiraju: "prostor", "mjesto" i "udaljenost". Ove su kategorije temeljne zemljopisne "realnosti" čiju "posebnost" proizvodi socioekonomska dinamika koja se u "prostoru" odvija kroz povijest između "mjesta" kao "spacijalnih koordinata", tako da utječe na stvaranje "okoliša" uz koji se vezuje određena "kultura". ${ }^{9}$ U tom se smislu taj prostor može odrediti istovremeno kao otvoreni socio-okolišni sustav koji ima svoju čvrstu "regionalnu strukturu" te tzv. "ulaznu" i "izlaznu" dinamiku koja intenzivno komunicira kako su nacionalnim tako i s međunarodnim okruženjem. ${ }^{10}$

2 Hrvoje KEKEZ, "Grb Republike Hrvatske: simbol, identitet i tradicija", Most - The Bridge, Glasilo Hrvatske katoličke misije u Londonu, 6/2012, 36. - 46.

3 Dov NIR, Region as a Socio-environmental System. An Introduction to a Systemic Regional Geography, Kluwer Academic Publishers, Dordrecht, Boston, New York, 1990.

4 Željko LOVRINČEVIĆ, Zdravko MARIĆ, Edo RAJH, "Kako optimalno regionalizirati Hrvatsku?" Hrvatsko društvo ekonomista, Zagreb, Ekonomski pregled, 56 (12)/2005, 1109. - 1160.

5 Ivan ROGIĆ, "Hrvatska i njezine regije", Institut društvenih znanosti Ivo Pilar, Društvena istraživanja, 1 (1)/1992, 25. - 34.; Zoran KLARIĆ, “Funkcija sjedišta županije i prometne veze kao čimbenici privlačnosti glavnih urbanih središta Hrvatske“, Hrvatsko geografsko društvo - Zadar, Odjel za geografiju, Sveučilište u Zadru, GeoAdria, 20 (1)/2016, 29. - 57.

6 Zakon o regionalnom razvoju Republike Hrvatske, Narodne Novine br. 147/2014.

7 Conor O'DWYER, "Reforming Regional Governance in East Central Europe: Europeanization or Domestic Politics as Usual?", Sage Journals, East European Politics and Societies, 20 (2)/2006, 219. - 253.

8 I. ROGIĆ, n. dj.

9 D. NIR, Region as a Socio-environmental System. An Introduction to a Systemic Regional Geography.

10 D. NIR, Isto, 89. - 96. 
Također, ovaj rad raspravlja o socioekonomskom razvoju sjeverozapadne Hrvatske iz modernizacijske perspektive koja $u$ središte modernizacijskog toka smješta procese industrijalizacije, urbanizacije i birokratizacije. ${ }^{11}$ Zbog toga je bitno imati na umu uvide po kojoj je modernizacija na sjeverozapadu Hrvatske počela ranije nego u drugim dijelovima Hrvatske. ${ }^{12}$ Također, u ovome se radu raniji i plodonosniji učinci modernizacije u sjeverozapadnoj Hrvatskoj kao zavičajnoj cjelini pripisuju i tome što to zemljopisno područje Republike Hrvatske nikad nije bilo pod osmanskom vlašću, ${ }^{13}$ kao i tome da je u razdoblju druge (paradoksalne) hrvatske modernizacije $^{14}$ na zavičajni okoliš sjeverozapadne Hrvatske povoljno utjecao "zapadni granični položaj". ${ }^{15}$ Ovaj je utjecaj umanjivao intenzitet tehnološkog i političkog jaza što ga je sustavno proizvodila zaostalost karakteristična za utjecaj centralno planske ekonomije u bivšem Istočnom Bloku ${ }^{16}$ Nadalje, u ovom se radu smatra da sve navedene okolnosti proizvode suvremenu situaciju po kojoj je sjeverozapadna Hrvatska (bez Grada Zagreba) područje koje ima najveću regionalnu konkurentnost $^{17} \mathrm{u}$ Republici Hrvatskoj ${ }^{18}$ a nalazi se i na vrhu ljestvice regionalne konkurentnosti prema makroekonomskim pokazateljima regionalne konkurentnosti koji su bili ispitivani radi uspoređivanja regionalnih razvojnih dispariteta prilikom pristupanja Republike Hrvatske Europskoj Uniji. ${ }^{19}$ Napokon, vodeći konkurentski položaj

${ }_{11}$ Ivan ROGIĆ, Tehnika i samostalnost. Hrvatska sveučilišna naklada, Zagreb, 2000.

12 I. ROGIĆ, Tehnika i samostalnost; Ivan OBADIĆ, “Međuodnos ljudi i rijeke Drave na području varaždinske Podravine u novom vijeku“" Hrvatska akademija znanosti i umjetnosti, Radovi Zavoda za znanstveni rad Varaždin, 18/2017, 301. - 325.

13 I. OBADIĆ, n. dj.; Mario HOLZNER, Amat ADAROV, Luka ŠIKIĆ, "Backwardness, Industrialisation and Economic Development in Europe: The Developmental Delay in Southeastern Europe and the Impact of the European Integration Process Since 1952", The wiiw Balkan Observatory Working Papers 123, 2016., June.

14 I. ROGIĆ, Tehnika $i$ samostalnost.

15 Saša POLJANEC-BORIĆ, “Razvoj Vukovarsko-srijemske županije u svjetlu socioekonomske tipologije endogenog razvitka u Hrvatskoj", Institut društvenih znanosti Ivo Pilar, Društvena istraživanja, 17 (1-2)/2008, 3. - 26.

16 M. HOLZNER, A. ADAROV, L. ŠIKIĆ, "Backwardness, Industrialisation and Economic Development in Europe: The Developmental Delay in Southeastern Europe and the Impact of the European Integration Process Since 1952", The wiiw Balkan Observatory Working Papers 123, 2016., June, 7. - 8.

17 U regresijski model regionalne konkurentnosti Republike Hrvatske u radu koji se ovdje citira uključene su sljedeće varijable: BDP po stanovniku na županijskoj razini dostupni za 2006., godinu kao zavisna je varijabla. Nezavisne varijable u modelu su: pokazatelji vanjskotrgovinske razmjene: izvoz po stanovniku (IPOP, u kn), izvozna ovisnost (IO, u \%) i uvozna ovisnost (UO, u \%), kao aproksimacije za trgovinsku otvorenost, gustoća cestovne mreže u m/km2 (G), kao aproksimativna varijabla kvalitete infrastrukture, broj upisanih studenata u tercijarno obrazovanje na 10000 stanovnika (ST), kao pokazatelj razine obrazovanja i BDP županija (u mil. kn, indeks $R H=100$ ), kao pokazatelj veličine tržišta (V) (vidi: Lela TIJANIĆ, "Regionalna (ne)konkurentnost u Republici Hrvatskoj", Hrvatsko društvo ekonomista, Zagreb, Ekonomski pregled, 61 (7-8)/2010, 430).

18 L. TIJANIĆ, n. dj. 429.

19 Isto, 428 
se, u ovom radu, hipotetski povezuje s većim socio-kulturnim kapitalom ${ }^{20}$ koji na ovom prostoru postoji zbog povijesnih razloga a čije je protezanje u suvremenost omogućena učincima sustavne otvorenosti ulazno - izlaznih dinamika ${ }^{21}$ koju trajno u Hrvatskoj proizvodi zapadni granični položaj ovog područja ${ }^{22}$ a kojima osobiti poticaj daje stvaranje unutrašnjeg europskog tržišta. ${ }^{23}$

Životni standard je koncept koji je usko povezan s algoritmom konkurentnosti ${ }^{24}$ a najčešće se definira kao lakoća kojom ljudi zadovoljavaju svoje potrebe. Taj se koncept posebno odnosi na fizičke uvjete u kojima ljudi žive, dobra i usluge koje mogu trošiti i resurse kojima imaju pristup. ${ }^{25}$ Istraživanja su pokazala da je $u$ Hrvatskoj od 2000. - do 2008. godine ostvaren kako kontinuiran rast BDP/per capita što je proizvelo i odgovarajući rast životnog standarda. ${ }^{26}$ Pored rasta životnog standarda u Hrvatskoj se, 2003. i 2006. godine, bilježi relativno visoka vrijednost indikatora općeg i subjektivnog osjećaja sreće ${ }^{27}$ dok je zadovoljstvo kvalitetom života bila nešto ispod prosjeka EU27. ${ }^{28} \mathrm{~S}$ obzirom da se rast životnog standarda može povezati s rastom zadovoljstva s kvalitetom života na nacionalnoj razini, razložno je zaključiti da je isto moguće učiniti i na regionalnoj razini. U tom je smislu opravdano pretpostaviti da je veća regionalna konkurentnost u sjeverozapadnoj Hrvatskoj, ${ }^{29}$ bila povezana kako s boljim životnim standardom tako i sa zadovoljstvom kvalitetom života u sjeverozapadnoj Hrvatskoj u odnosu na druge dijelove Republike Hrvatske.

Polazeći od pretpostavke da je interes nacionalnih javnih politika očuvati pa i ojačati konkurentnost na cijelom teritoriju Republike Hrvatske, razložno je istu logiku primijeniti i na lokalnu samoupravu u sjeverozapadnoj Hrvatskoj. Naime, rast blagostanja na jednom dijelu teritorija Republike Hrvatske neosporno pridonosi kako rastu ukupnog nacionalnog blagostanja mjerenog BDP/per capita tako i većem općem i subjektivnom osjećaju zadovoljstva životom u zavičajnom okruženju.

20 Robert PUTNAM, "The Prosperous Community", The American Prospect, 4 (13)/1993, 35. - 42.

21 D. NIR, Region as a Socio-environmental System. An Introduction to a Systemic Regional Geography.

22 S. POLJANEC-BORIĆ, n. dj.

${ }_{23}$ M. HOLZNER, A. ADAROV, L. ŠIKIĆ, "Backwardness, Industrialisation and Economic Development in Europe: The Developmental Delay in Southeastern Europe and the Impact of the European Integration Process Since 1952“", The wiiw Balkan Observatory Working Papers 123, 2016., June, 7.

24 Michael E. PORTER, The Competitive Advantage of Nations, The Free Press, New York, 1998.a.

25 Dajana CVRLJE, Tomislav ĆORIĆ, “Macro \& Micro Aspects of Standard of Living and Quality of Life in a Small Transition Economy: The Case of Croatia“, Ekonomski fakultet Sveučilišta u Zagrebu, Working Paper Series, 2/2010, 4.

26 Isto, 5.

27 Predrag BEJAKOVIĆ, Ljiljana KALITERNA-LIPOVČAN, Quality of Life in Croatia: Key Findings from National Research, European Foundation for the Improvement of Living and Working Conditions, Dublin, 2007., 36.

28 D. CVRLJE, T. ĆORIĆ, n. dj., 10.

29 L. TIJANIĆ, n. dj. 
Zbog toga je važno u nastavku razmotriti perspektive razvoja sjeverozapadne Hrvatske u postojećim europskim regionalnim okvirima imajući na umu veliku volatilnost regionalnih politika osobito u Srednjoj, Istočnoj i Jugoistočnoj Europi, što može bitno utjecati na regionalni razvoj u tim državama. Iako se smatralo da će, pod pritiskom europskih integracija, regionalne politike utjecati na europeizaciju administrativne politike u novopridošlim članicama EU te time povećati utjecaj EU, ipak se pokazuje da na te procese više utječe domaća politička scena, što je osobito vidljivo iz komparacije, poljskog, češkog i slovačkog slučaja. ${ }^{30}$ No, u ovom je kontekstu značajno istaći da postoje i uvidi druge vrste po kojima je optimizirana regionalizacija teritorija značajan poticaju rastu i razvoju $\mathrm{u}^{31}$ bez obzira na to izvire li ona iz nacionalne ili europske dinamike. Zbog toga je bitno razumjeti položaj sjeverozapadne Hrvatske u tekućoj europskoj regionalizacijskoj dinamici jer to razumijevanje može imati pozitivan (katalitički) utjecaj32 na društveno ekonomski razvoj tog područja.

\section{SJEVEROZAPADNA HRVATSKA U KONTEKSTU PRIJEPORA VEZANIH ZA NACIONALNI ADMINISTRATIVNI USTROJ I STATISTIČKU REGIONALIZACIJU}

Polazeći od spoznaje da je koncept regije višedimenzionalan pa može biti utemeljen u ekonomskim, etničkim, političkim, fizičkim i misaonim faktorima ${ }^{33}$ ponajprije je, za potrebe ovog rada, potrebno utvrditi suštinsku razliku između regionalne i županijske organizacije teritorija. $U$ tom je smislu bitno naznačiti da je

30 Conor O'DWYER, n. dj.

31 Bjørn T. ASHEIM, Arne ISAKSEN, “Location, agglomeration and innovation: Towards regional innovation systems in Norway?", Taylor \& Francis Online, European Planning Studies, Vol. 5, Issue 3: Globalization, Regional and Local Knowledge Transfer / 2007, 299. - 330.

32 Clayton M. CHRISTENSEN, Heiner BAUMANN, Rudi RUGGLES, Thomas M. SADTLER, “Disruptive Innovation for Social Change", HBSPC, Harvard Business Review, December Issue/2006. http://www. cnid.cl/wp-content/uploads/2015/10/Disruptive-Innovation-for-Social-Change_2006.pdf (20. 10. 2016.). Navedeni autori tvrde da katalitički inovatori imaju 5 kvaliteta: 1) stvaraju sistemsku društvenu promjenu kroz razmjernost i umnožavanje, 2) odgovaraju na podusluženost (postojeća rješenja su složenija nego što je to ljudima potrebnu) ili na neusluženost, 3) Nude proizvode i usluge koje su jednostavnije i jeftinije nego alternative i mogu biti percipirane kao niža razina izvedbe ali ih korisnici smatraju dovoljno dobrima, 4) stvaraju resurse kao što su donacije, zaklade, dobrovoljni rad ili intelektualni kapital na način koji je na početku neprivlačan utvrđenim takmičarima, d) često su zaobilaženi, obezvrijeđeni ili čak poticani od strane postojećih suparnika za koje je taj poslovni model neprofitabilan ili uopće neprivlačan i koji stoga izbjegavaju ili se povlače iz tih tržišnih segmenata (Isto, 3).

33 Paul CLAVAL, Régions, nations, grands espaces, Genin, Paris, 1968.; Jacqueline BEAUJEU-GARNIER, La géographie: méthodes et perspectives, Masson, Paris, 1971.; Pero MALDINI, "Politički i administrativni aspekti regije: regionalizam, regionalizacija i regionalna politika", Sveučilište u Dubrovniku, 1. Zbornik Sveučilišta u Dubrovniku, 1 (1)/2014, 125. - 153. 
smisao županijskog ustroja uglavnom administrativan, dakle, jednodimenzionalan, njegova je primarna misija izgradnja: "primjerene upravne teritorijalne sheme kako bi država mogla funkcionirati stvarajući jedinstveni pravni poredak na cijelom teritoriju kojim raspolaže .... (pa je stoga op. a.) .... cilj županije upravna homogenizacija zemlje". ${ }^{34}$

$\mathrm{S}$ druge je strane cilj regije okolišna i kulturna diferencijacija zemlje. ${ }^{35} \mathrm{No}$, u uvjetima u kojima su: "nacija i nacionalna država postali glavni oblici političke i teritorijalne identifikacije ... (te $u$ uvjetima op. a.) ... suvremenih postmodernih $i$ globaliziranih društava, poglavito onih najrazvijenijih, regionalizam poprima drukčije značenje. Od nekadašnjega oponiranja centrifugalnoj dinamici političke unitarizacije s naglašenim obilježjima tradicionalizma i konzervativizma, regionalizam se sve više iskazuje kao liberalistički zahtjev za većim stupnjem demokratičnosti, za ostvarenjem građanskih prava (manjinskih, etničkih) i za primicanjem procesa političkog odlučivanja što bliže građanima i mjestu njihova svakodnevnog življenja ... regionalizam se tako pojavljuje kao zahtjev za većim stupnjem demokratičnosti i administrativne racionalnosti, poglavito s obzirom na nedostatnu responzivnost središnjih državnih institucija prema zahtjevima društva i njihov nedostatan kapacitet $\mathrm{u}$ zadovoljavanju potreba građana na lokalnim razinama, dakle, kao zahtjev periferije za decentralizacijom upravljanja nad javnim dobrom “ ${ }^{36}$ Drugim riječima, regionalizam u suvremenom političkom kontekstu pretežito afirmira posebnosti socio-ekonomske dinamike određenih zavičajnih područja koji su teritorijalno povezana u nacionalni teritorij.

U Republici Hrvatskoj se sustav nacionalnog administriranja teritorija kroz sustav županija pokazao dobro prihvaćenim u lokalnim samoupravama. ${ }^{37} \mathrm{No}, \mathrm{u}$ uvjetima europskih integracija takvom sustavu nacionalnog administriranja nedostajala je NUTS 2 razina koju je valjalo upotpuniti optimalnom varijantom statističke regionalizacije koja će se temeljiti na tri kriterija: broju stanovnika, financijskom učinku od pristupa strukturnim fondovima i homogenosti pojedinih regija. $U$ tom su svjetlu Lovrinčević i sur. ${ }^{38}$ razradili čak 8 varijanti statističke regionalizacije Hrvatske od kojih su 5 varijanti sugerirale formiranje 3 statističke regije, 2 su varijante sugerirale formiranje 4 statističke regije a jedna je varijanta sugerirala uspostavu 2 statističke regije u Republici Hrvatskoj. Vrijeme je pokazalo da je Republika

34 I. ROGIĆ, n. dj., 32.

35 P. CLAVAL, Régions, nations, grands espaces; D. NIR, Region as a Socio-environmental System. An Introduction to a Systemic Regional Geography; I. ROGIĆ, n. dj.

36 P. MALDINI, n. dj., 127.

37 Z. KLARIĆ, n. dj.

38 Ž. LOVRINČEVIĆ, Z. MARIĆ, E. RAJH, n. dj. 
Hrvatska u procesu pristupanja Europskoj Uniji izabrala upravo varijantu s 2 statističke regije koju su spomenuti autori razmatrali kao varijantu broj $8 .{ }^{39}$ Razložno je pretpostaviti da je to učinjeno zato što ta varijanta "osigurava zadovoljavanje kriterija broja stanovnika i maksimalan iznos potencijalnih sredstva ${ }^{40} \mathrm{iz}$ EU fondova. No, nedostaci su te varijante izrazito nedovoljna razina interregionalne heterogenosti i intraregionalne homogenosti (Grad Zagreb po svojim karakteristikama izdvaja se od ostalih županija kontinentalne regije). Dalje, zbog heterogenosti ukupnog hrvatskog prostora ova varijanta nudi dvije velike regije i značajno otežava formuliranje i praćenje učinaka regionalne politike. Ona bi vjerojatno državnoj administraciji bila prihvatljiva zbog očekivanog financijskog učinka, ali stručna analiza ukazuje na nekvalitetnu osnovicu koju bi ta varijanta predstavljala za dugoročno vođenje regionalne politike“. ${ }^{41}$

Zaključno gore navedeni autori naglašavaju sljedeće: "Ako se naglasak u potpunosti stavi na očekivane financijske učinke, a zanemare se kriteriji homogenosti i mogućnosti vođenja konzistentne regionalne politike, nego se ustraje u potpunosti na bottom up pristupu tada se varijanta 8 (podjela na dvije NUTS 2 regije) nameće kao rješenje. Kratkoročno gledano, ta se varijanta čini prihvatljivom, jer ne dovodi u pitanje Eurostatov minimalan-maksimalan kriterij broja ljudi i ne zahtijeva pregovore o strukturi hrvatskih NUTS 2 regija. No, zbog nesposobnosti i brojnosti najmanjih lokalnih jedinica (praktično općina) da u ovom trenutku generiraju i valoriziraju razvojne programe i zbog razine složenosti problema s kojima se pojedine od njih susreću, ona može imati dugoročno negativne učinke na razvitak Hrvatske. Filozofija razvitka varijante $8 \mathrm{u}$ potpunosti podrazumijeva bottom - up regionalnu politiku razvitka za koju Hrvatska nema preduvjete (fiskalne, ljudske, institucionalne) “. ${ }^{42}$

Očito je, dakle, da europska statistička regionalizacija u odnosu na nacionalni administrativni režim ima nekoliko značajki: a) preskače povijesnu regionalizaciju Hrvatske koja je simbolički prisutna u nacionalnoj zastavi na način da grb ima "krunu" od pet hrvatskih povijesnih regija, ${ }^{43}$ b) umanjuje mogućnosti vođenja regionalne politike na načelima regionalne homogenosti c) stimulira "odozdo prema gore" razvojni pristup d) maksimizira mogućnost povlačenja sredstava iz EU fondova za sve zainteresirane dionike. Hoće li ta regionalizacija imati katalitički utjecaj na društveni razvoj ${ }^{44}$ sjeverozapadne Hrvatske još nije jasno ali je jasno da je upravni model

\footnotetext{
39 Isto, 1139.

40 Podebljani dijelovi rečenica u citatu prenose se iz izvornog teksta (op. a.).

41 Ž. LOVRINČEVIĆ, Z. MARIĆ, E. RAJH, n. dj., 1155.

42 Isto, 1157.

43 H. KEKEZ, n. dj.

${ }_{44}$ C. M. CHRISTENSEN, H. BAUMANN, R. RUGGLES, T. M. SADTLER, n. dj.
} 
koji se odnosi na NUTS 3 razinu organizacije uprave, dakle, na sustav županija, izložen oštrim kritikama od kojih je najoštrija ona koju definira Koprić. ${ }^{45}$

Temelj Koprićeve kritike je dvostupanjski sustav lokalne samouprave koji funkcionira od 1993. godine. ${ }^{46} \mathrm{U}$ tom su sustavu tri su temeljne skupine jedinica općine, gradovi te županije koje, po Kopriću, čine neuravnoteženu teritorijalnu mrežu. Preciznije Koprićeva argumentacija izgleda kako slijedi:

“... Unutar svake od tih kategorija postoje velike razlike u veličini i razvojnom kapacitetu. Postoje općine s manje od 500 stanovnika i one preko 10.000; neki gradovi imaju manje od 3.000 stanovnika pa su manji od nekih općina; najmanja županija ima devet puta manje stanovnika od najveće, itd. Od 2005. postoji i kategorija velikih gradova (16), s preko 35.000 stanovnika. S njima su odmah izjednačeni i gradovi sjedišta županija (njih 8), bez obzira na veličinu, s tim da među njima ima i gradova s manje od 10.000 stanovnika. To je umjesto očekivanog naglašavanja razvojne uloge gradova pridonijelo petrifikaciji županijske strukture. Pored toga, postoje posebni statusi koji obuhvaćaju preko polovice lokalnih jedinica (njih 279). To su jedinice na područjima posebne državne skrbi (184), na brdsko-planinskom području (45), te na otocima (50). Posebni status imaju također gradovi Vukovar i Zagreb, reguliran dvama posebnim zakonima, ali iz različitih razloga. Grad Zagreb sa 792.875 stanovnika praktično je jedini grad sa značajnim prenesenim djelokrugom, tj. poslovima državne uprave, koje obavlja za središnju državu, bez financijske naknade, koristeći vlastito upravno osoblje. Neuravnotežena teritorijalna struktura dovodi u nejednak položaj stanovnike i poduzetnike. Ogromna je razlika u razvojnom potencijalu i kvaliteti života između većine općina i nekoliko najvećih gradova, što potiče migraciju prema najvećim urbanim centrima, a posebno prema Zagrebu čije se gravitacijsko djelovanje stalno pojačava. Postavlja se pitanje je li takva visoko fragmentirana i neizbalansirana struktura doista samo odraz različitih uvjeta na terenu? Da li doista gradske četvrti Grada Zagreba, svaka s prosječno 46,5 tisuća stanovnika, što je za 10.000 iznad donje granice za velike gradove, trebaju biti - po toj nekoj imaginarnoj naravi stvari - obespravljenije od najmanje općine u zaleđu Zadra ili Šibenika, ili u Zagorju odnosno Međimurju? Je li takva struktura doista prikladna uvjetima ili je dizajner ovog sustava potpuno arbitraran u njegovom oblikovanju?" ${ }^{47}$

45 Ivan KOPRIĆ, “Lokalna samouprava u Hrvatskoj: pokvarena igračka u rukama politike", 1. Forum za javnu upravu, Zaklada Friedrich Ebert i Institut za javnu upravu, Zagreb, 2012, 7. - 28.; Ivan KOPRIĆ, "Je li moguća regionalizacija Hrvatske? Institucionalna i politička ograničenja", Fakultet političkih znanosti Sveučilišta u Zagrebu, Političke analize, 5 (17)/2014, 9. - 16.

46 I. KOPRIĆ, "Lokalna samouprava u Hrvatskoj: pokvarena igračka u rukama politike", 1. Forum za javnu upravu, Zaklada Friedrich Ebert i Institut za javnu upravu, Zagreb, 2012, 7. - 28.

47 Isto, 4. -5 . 
Naglašavajući da ovakva teritorijalna organizacija zemlje ne može proizvesti ravnomjeran razvoj zemlje, Koprić tvrdi da je od pet glavnih poslovnih misija nacionalne administracije (upravna, politička, socijalna, ekonomska i ekološka) hrvatska lokalna samouprava najviše posvećena političkoj, u jednoj manjoj mjeri socijalnoj a tek marginalno ekonomskoj i ekološkoj misiji. ${ }^{48}$ To, tvrdi on, proizvodi probleme kao što su: "neujednačena teritorijalna struktura, problemi u pravnoj regulaciji pretjerano skučenog lokalnog djelokruga, ograničavanje lokalnih prihoda koje onemogućuje obavljanje šireg kruga javnih službi za lokalno stanovništvo i za zajednicu, mali potencijali razvoja infrastrukture i nedovoljna usmjerenost na razvoj, stalni problemi s političkim legitimitetom lokalnih organa, nedostatak menadžera i sposobnih lokalnih vođa, nepostojanje sustava edukacije za rad u lokalnoj samoupravi, kao i gotovo potpuni izostanak financiranja znanstveno-istraživačkih projekata iz tog područja, niska profesionalnost upravnog osoblja, onemogućavanje utjecaja lokalnih jedinica na nacionalne javne politike koje ih se tiču, nesustavan i parcijalan nadzor usmjeren na kažnjavanje a ne na poboljšanje lokalne samouprave“. ${ }^{49}$ Stoga predlaže uspostavu "150 općina sa širokim samoupravnim djelokrugom i solidnim izvorima prihoda te pet samoupravnih regija koje odražavaju realne okolnosti Hrvatske. Jedna od tih regija bila bi metropolitanska regija Zagreba, organizirana po modelu metropolitanske federacije“, ${ }^{50}$ čime izravno dovodi u pitanje postojeći NUTS 3 (županijski) administrativni sustav u Hrvatskoj.

U radu iz 2014. godine isti autor dalje zagovara stvaranje višestupanjskog sustava javnog upravljanja u Hrvatskoj zbog toga što je postojeći sustav lokalne samouprave lišen pravog regionalnog okvira i uloge, ${ }^{51}$ mnoge od jedinica lokalne samouprave nemaju institucionalnog kapaciteta da obavljaju javne poslove pa umjesto njih te poslove obavljaju županije što predstavlja neustavno stanje. ${ }^{52}$ Zato se autor izrazito zalaže za formiranje samoupravnih političkih regija pri čemu je najvažnije "kvalitetno povući crte razgraničenja regija u središnjem dijelu Hrvatske u široj okolici Zagreba, ne libeći se pritom rješenja koje će čak i neke dijelove sada bliže Zagrebu smjestiti u neke druge regije ${ }^{\text {" }}{ }^{3} \mathrm{Kad}$ je riječ o definiranju konkretnih regija autor se posebno zalaže za formiranje pet samoupravnih (političkih) regija i to: Zagrebačka, Primorsko - istarsko - gorska, Dalmacija, Slavonija te Središnja Hrvatska. ${ }^{54}$ Time bi se "dobila relativno uravnotežena regionalna struktura, uz stanovito odstupanje

\footnotetext{
Isto, 16.

Isto, 16.

Isto, 16.

I. KOPRIĆ, n. dj., 9.

Isto, 11. -12 .

Isto, 12 .

4 Isto, 12. -13 .
} 
u Zagrebačkoj regiji te Primorsko-istarsko-gorskoj regiji... No, unutarregionalne autonomije trebalo bi formirati ne samo za Istru nego vjerojatno i za dubrovačko područja, Međimurje, Zadar, Zapadnu Slavoniju te Baranju. ... Čak i ti takvi posebni slučajevi mogu se regulirati međusobno različito tj. tako da npr. Istra kao subregija ima različite ovlasti od područja oko Dubrovnika. Nema zapreke za fleksibilan pristup i očuvanje identiteta pojedinih subregija". ${ }^{55}$

Predložena politička regionalizacija koristila bi se i kao predložak za izborne jedinice za izbor zastupnika u Hrvatski sabor. Naime, "postojeće izborne jedinice nisu skrojene logično te dijele prostor Republike Hrvatske u smislu izbornog inženjeringa a ne prema logičnim vezama pojedinog dijela državnog teritorija ${ }^{56} \ldots$ Organizacijom izbora za Sabor u pet samoupravnih regija Hrvatski sabor dobio bi neku vrstu regionalnog predstavništva te bi bilo nešto jasnije nego sada koji zastupnici predstavljaju koji dio birača u zemlji... Broj zastupnika treba vezati uz broj birača, što znači da svaka regija vjerojatno ne bi imala jednak broj zastupnika $u$ Saboru, s obzirom na to da bi se ipak značajnije razlikovale po broju stanovnika". ${ }^{57}$

Iz navedenog je citata jasno vidljivo da ovakav pristup novoj regionalizaciji Republike Hrvatske zahtjeva radikalne izmjene postojećih administrativnih režima u Republici Hrvatskoj, na način da potpuno rekonstruiraju postojeću NUTS 3 (županijsku) razinu ali ne dovode u pitanje postojeću NUTS 2 razinu statističkih regija. Zbog toga je jasno da Koprićevi prijedlozi primarno teže promijeniti dvije administrativne mreže: a) onu razinu nacionalnog administriranja teritorija kojoj je cilj administrativna homogenizacija teritorija ${ }^{58}$ i b) izbornu organizaciju teritorija. ${ }^{59}$ Smatra se, naime, da takva organizacija: a) previše centralizira sustav uprave u Republici Hrvatskoj i b) ne osigurava predstavništva regija ili dijelova Hrvatske u Saboru ${ }^{60}$ pa zapravo priječi društveno ekonomski razvoj Hrvatske. Iz toga posredno slijedi da je europska regionalizacija (NUTS 2) formalno prihvatljiva dok je nacionalna administrativna organizacija na razini NUTS 3 administrativnih jedinica pravno i razvojno deficitarna. Ona, u osnovi predstavlja prepreku društveno ekonomskom razvoju Hrvatske ${ }^{61}$ jer pretjerano administrativno fragmentira zemlju

\footnotetext{
Isto, 13.

56 Tvrdi se da su postojeće izborne jedinice za izbor zastupnika u Hrvatski sabor utvrđene još u vrijeme kad se Sabor sastojao od Zastupničkog i od Županijskog doma (I. KOPRIĆ, n. dj., 14).

57 Isto, 13.

58 I. ROGIĆ, n. dj.

59 Zakon o izbornim jedinicama za izbor zastupnika u zastupnički dom Hrvatskog državnog sabora, Narodne Novine br. 116/1999.

60 I. KOPRIĆ, n. dj. 14.

${ }^{61}$ I. KOPRIĆ, “Lokalna samouprava u Hrvatskoj: pokvarena igračka u rukama politike", 1. Forum za javnu upravu, Zaklada Friedrich Ebert i Institut za javnu upravu, Zagreb, 2012, 7. - 28.
} 
i time izbija upravi alate za vođenje poticajnih razvojnih politika. Osim toga, administrativnu organizaciju zemlje po županijama dijeli od političke organizacije zemlje po izbornim jedinicama. Time blokira realnu reprezentaciju povezanu s regionalnim socio-ekonomskim kapacitetima pojedinih dijelova zemlje. Ovo, pak, nepotrebno sužava misiju uprave samo na njenu političku i socijalnu funkciju, zanemarujući onu ustavno pravnu, ekonomsku i ekološku. Imajući u vidu činjenicu da Koprićevi stavovi predstavljaju najoštriju među brojnim raspravama posvećenim regionalizaciji Hrvatske $^{62}$ koji su objavljeni u posljednjih 15 godina, zanimljivo je pogledati kako se u prema navedenim i ostalim dostupnim uvidima o regionalizaciji Hrvatske a posebice prema Koprićevim odnosi Zakon o regionalnom razvoju Republike Hrvatske $^{63}$ koji je na snagu stupio u siječnju 2015. godine.

Već je iz Općih odredbi ovog Zakona jasno da je njegova osnovna svrha postići što učinkovitije korištenje fondova Europske unije jer se njime, zapravo, stvara pravni temelj za provedbu Uredbe broj 1301/2013 Europskog parlamenta i Vijeća od 17. prosinca, 2013. godine o Europskom fondu za regionalni razvoj te posebnim odredbama cilja "Ulaganje za rast i radna mjesta" ${ }^{64}$ Eksplicitno se kaže da je: “Cilj politike regionalnog razvoja pridonijeti društveno - gospodarskom razvoju Republike Hrvatske, u skladu s načelima održivog razvoja, stvaranjem uvjeta koji će svim dijelovima zemlje omogućavati jačanje konkurentnosti i realizaciju vlastitih razvojnih potencijala" ${ }^{65}$ Nadalje, u svjetlu ovog Zakona politika regionalnog razvoja sastoji se u tome da se osigura: "Povezanost lokalnih i regionalnih razvojnih potreba s prioritetima razvoja središnje razine te ciljevima kohezijske politike Europske unije; potpora slabije razvijenim područjima za povećanje i optimalno korištenje vlastitog razvojnog potencijala otklanjanjem uzroka razvojnih teškoća; odgovarajuće mjere za ravnomjeran i održiv razvoj jedinica lokalne i područne (regionalne) samouprave u pograničnom području; poticanje teritorijalne suradnje te učinkovito korištenje sredstava strukturnih i investicijskih fondova europske unije namijenjenih regionalnom i

62 Sanja MALEKOVIĆ, Jakša PULJIZ, “Izazovi novog pristupa upravljanju razvojem na lokalnoj i regionalnoj razini u Hrvatskoj", Nova hrvatska lokalna i regionalna samouprava, Hrvatska akademija znanosti i umjetnosti, ur. Jakša BARBIĆ, Zagreb, 2010., 199. - 222.; Damir MAGAŠ, “Koncept teritorijalnog ustroja Jadranske Hrvatske“, Hrvatsko geografsko društvo - Zadar, Odjel za geografiju, Sveučilište u Zadru, GeoAdria, 16 (2)/2011, 211. - 236.; Damir MAGAŠ, "Jadranska Hrvatska iz perspektive regionalizacije Europske Unije", Fakultet političkih znanosti Sveučilišta u Zagrebu, Političke analize, 5 (17)/2014, 23. - 29.; Aleksandar TOSKIĆ, Dražen NJEGAČ, "Changes in Political and Territorial Organization and their Impact on Croatia's Urban System and Regional Development", Hrvatsko geografsko društvo, Hrvatski geografski glasnik, 65 (1)/2003, 7. - 24.

63 Zakon o regionalnom razvoju Republike Hrvatske, Narodne Novine br. 147/2014.

64 Zakon o regionalnom razvoju Republike Hrvatske, Narodne Novine br. 147/2014, čl. 1.

65 Zakon o regionalnom razvoju Republike Hrvatske, Narodne Novine br. 147/2014, čl. 2. 
urbanom razvoju“ . ${ }^{66}$ Imajući u vidu navedene svrhe i ciljeva Zakona koji je na snagu stupio 1. siječnja, 2015. godine, zanimljivo je istaći da je: a) iz članka 13 spomenutog Zakona razvidno da županije ostaju bitnim dijelom "europskog koncepta" regionalnog razvoja koji se definira ovim zakonom; b) iz članka 14 razvidno da novi "europski koncept" regionalnog razvoja uvodi $\mathrm{u}$ institucionalnu proceduru četiri urbane aglomeracije sa sjedištima u Zagrebu, Splitu, Rijeci i Osijeku te da Zakon stimulira međusobno povezivanje manjih urbanih područja; c) iz članka 15 razvidno da spomenuti gradovi postaju strateški nositelji razvojnih koncepta urbanih aglomeracija; d) iz članka 17 je razvidno da je ključni nositelj politike regionalnog razvoja Ministarstvo, dakle, tijelo središnje države koja će regionalnu prisutnost osiguravati kroz Vijeće za regionalni razvoj (čl. 18) i kroz Partnersko vijeće statističke regije (čl. 21). Iz toga slijedi da će se odluke Ministarstva donositi kroz dogovor ključnih institucionalnih dionika u procesu.

Sve u svemu jasno je da ovaj Zakon ne polemizira sa županijskim administrativnim ustrojem Hrvatske ali da u postojeći ustroj intervenira kako odredbom o urbanim aglomeracijama koje dobivaju stratešku autonomiju tako i odredbom o partnerskim vijećima statističke regije, čime će se utjecaj županija na politiku regionalnog razvoja sigurno smanjiti. U tom je smislu opći dojam da zakon otvara širok prostor raznim oblicima institucionalne suradnje u svrhu množenja projektnih inicijativa i kumuliranja projektnih interesa. Ipak, može se pretpostaviti da će statističke regije u tim zakonskim uvjetima biti kako pod jačim utjecajem urbanih aglomeracija tako i pod utjecajem središnje države s obzirom da se njen zakonski položaj može funkcionalno prevesti kao koordinacijsko vodstvo. Ipak, ne treba isključiti mogućnost da Zakon ponekad otvori prostor i za druge vrste saveza na županijskim i lokalnim razinama. Teško je, naime, zamisliti demokraciju u kojoj bi ovako složen institucionalni ustroj mogao biti potpuno podređen volji središnje države i/ ili velikih gradova u uvjetima u kojima se financiranje projekata verificira na drugim (europskim) instancama.

Imajući u vidu vremenski horizont u kojem je taj Zakon donesen, kao i činjenicu da je on stupio na snagu 1. siječnja, 2015. godine, dakle u vrijeme kad je stručna rasprava o reorganizaciji regionalnog ustroja zemlje bila najdinamičnija, razložno je zaključiti da Zakon nije uzeo u obzir oštru kritiku administrativnog ustroja na NUTS 3 razini koja u Hrvatskoj podrazumijeva županijskih ustroj ali je uzeo u obzir nodalno-funkcionalni kriterij koji u posebni razvojni fokus stavlja i "ne - županijske" aktere a to su četiri urbane aglomeracije sa sjedištima u Zagrebu, Splitu, Rijeci i Osijeku. Uz to Zakon je posebno naglasio potrebu međusobnog povezivanja

\footnotetext{
66 Zakon o regionalnom razvoju Republike Hrvatske, Narodne Novine br. 147/2014, čl. 2.
} 
manjih urbanih područja kako bi tom formulacijom napravio institucionalni prostor za konkurentsku borbu kolaborativnih projekta "manjih urbanih područja" s onima koje će, eventualno, za financiranje predlagati Zagreb, Split, Rijeka i Osijek. Iz toga se može zaključiti da je županijska administrativna organizacija zemlje preživjela sve reformske zahvate koji su se, u posljednjih nekoliko godina, u vrijeme pisanja i donošenja Zakona o regionalnom razvoju predlagali ali je njen razvojni utjecaj znatno umanjen definiranjem urbanih aglomeracija kao jakih razvojnih aktera te zakonskom afirmacijom "manjih urbanih područja“. Opravdano je zaključiti da je ovim zakonskim rješenjima zapravo, u Zakon, uvršten dio rasprava povezanih $\mathrm{s}$ potrebom novog regionalnog ustroja zemlje iako je jasno da niti jedan od prijedloga nije bio usvojen cjelovito. $S$ obzirom da se Zakonom propisani uvjeti pod kojima se provodi regionalna politika razvoja u okviru Europske unije mogu smatrati okvirom kojem će se morati prilagoditi svi zainteresirani razvoji akteri u Hrvatskoj, korisno je u socioekonomskoj perspektivi sagledati položaj sjeverozapadne Hrvatske u postojećem regionalnom (razvojnom) okviru.

\section{SJEVEROZAPADNA HRVATSKA: PODREGIJA S ELASTIČNIM PROSTORNIM OBUHVATOM}

Polazeći od prethodno objašnjene spoznaje da je kvaliteta života u sjeverozapadnoj Hrvatskoj refleks konkurentnosti utemeljene na više strukturnih dimenzija koje karakteriziraju taj prostor, razložno je u nastavku pokušati objasniti zašto se u uvjetima europskih integracija sjeverozapadna Hrvatska može zamisliti kao "elastična pod-regija" čiji obuhvat se mijenja s obzirom na "cluster" koji se u pojedinoj razvojnoj perspektivi promatra. U tu svrhu valja najprije podsjetiti na činjenicu da se pojam regije u Hrvatskoj, sukladno Zakonu o regionalnom razvoju, već odnosi na pojam "statističke regije". ${ }^{67}$ Pored toga, županije su u nacionalnom i europskom administrativnom sustavu ostale službeni dio nacionalne uprave koja u europskoj nomenklaturi predstavlja NUTS 3 razinu dok su, unutar statističke regije, u okviru Zakona o regionalnom razvoju, određene kao realni razvojni akteri. Stoga bi korištenje pojma "regije" za prostor Sjeverozapadne Hrvatske koji de iure nema upravni položaj regije u postojećem nacionalnom i europskom upravnom sustavu unosilo veliku zbrku u sinergijskim razvojnim inicijativama koje će na prostoru sjeverozapadne Hrvatske nastajati u svrhu realiziranja projekata utemeljenih na preciznom administriranju karakterističnom za povlačenje sredstava iz Europske unije.

\footnotetext{
${ }_{67}$ Zakon o regionalnom razvoju Republike Hrvatske, Narodne Novine br. 147/2014.
} 
S druge strane, sasvim je jasno da su relevantne analize kao što su: multivarijantna klasifikacija županija Hrvatske koja je provedena metodom multivarijantne analize deset odabranih socioekonomskih pokazatelja u veće homogene prostorne jedinice $^{68}$ i regresijski model regionalne konkurentnosti ${ }^{69}$ pokazale da Sjeverozapadna Hrvatska (koja obuhvaća prostor pet županija: Zagrebačke, Krapinsko-zagorske, Varaždinske, Međimurske i Koprivničko-križevačke) posjeduju homogenost karakterističnu za koncept regije u kojoj postoje "clusteri". "Cluster" je, prema Porteru ${ }^{70}$ zemljopisna koncentracija međusobno povezanih proizvodnih tvrtki unutar istih industrija i institucija koji uključuju: opskrbljivače dijelova za proizvodnju, strojeva, usluga i specijalizirane infrastrukture. Spomenuta zemljopisna koncentracija i međusobna povezanost poduzeća sa posebnim tipovima infrastrukture čine "cluster", moćnim razvojnim akterom koji ne utječe samo na socio-ekonomsku dinamiku unutar "cluster-a" nego i na "proizvođače komplementarnih proizvoda, dobavljače specijalizirane infrastrukture i ostale institucije koje pružaju specijalizirane vještina, obrazovanje, informacije, istraživanje i tehničku podršku kao što su sveučilišta, "think-tanks", stručno usavršavanje i agencije za standardizaciju (...) trgovačka udruženja i druga zajednička tijela koja pokrivaju djelatnost "clustera". ${ }^{71}$

Iz "clustera" izvire konkurentnost koja ne ovisi samo o produktivnosti poduzeća unutar pojedinih industrija ${ }^{72}$ nego i iz produktivnosti koju proizvodi "cluster": "Profinjenost s kojom se tvrtke natječu u određenoj lokaciji se pod jakim utjecajem poslovne klime. Na primjer, tvrtke ne mogu upotrijebiti napredne logističke pristupe ako ne postoji visoko kvalitetna transportna infrastruktura. Tvrtke se ne mogu natjecati s visoko uslužnim strategijama ako nemaju dobro obrazovane ljude. Ako

${ }_{68}$ Deset socioekonomskih pokazatelja navodi se kako slijedi: bruto domaći proizvod po stanovniku u kunama, stopa registrirane nezaposlenosti, zaposleni u primarnom sektoru na 1.000 stanovnika, zaposleni u sekundarnom sektoru na 1.000 stanovnika, zaposleni $\mathrm{u}$ tercijarnom sektoru na 1.000 stanovnika, koeficijent pokrivenosti uvoza izvozom, promet s PDV-om trgovina na malo po stanovniku, doktori medicine na 10.000 stanovnika, zubni terapeuti na 10.000 stanovnika i vrijednost prodaje industrijskih proizvoda u industrijskim lokalnim jedinicama u tisućama kuna (vidi: Nataša KURNOGA ŽIVADINOVIĆ, "Multivarijantna klasifikacija županija Hrvatske", Ekonomski fakultet Zagreb, Zbornik Ekonomskog fakulteta u Zagrebu, 5 (1)/2007, 3). N. KURNOGA ŽIVADINOVIĆ, Isto, 14.

69 L. TIJANIĆ, n. dj., 430. - 435.

70 M. E. PORTER, The Competitive Advantage of Nations; Michael E. PORTER, “The Adam Smith Address: Location, Clusters, and the New Microeconomics of Competition". National Association for Business Economics, 39 ${ }^{\text {th }}$ Annual Meeting of NABE, New Orleans, LA, September $14-17,1997,1998 . b$.

71 M. E. PORTER, "The Adam Smith Address: Location, Clusters, and the New Microeconomics of Competition". National Association for Business Economics, $39^{\text {th }}$ Annual Meeting of NABE, New Orleans, LA, September $14-17,1997,1998 . b, 10$.

72 "Ključna analitička jedinica za razumijevanje konkurentnosti je industrija. Industrija (bilo proizvodna ili uslužna) je grupa konkurenata koji stvaraju proizvode ili usluge što se međusobno natječu. Strateški različita industrija obuhvaća proizvode u kojoj su izvori konkurentske prednosti slični“ (M. E. PORTER, The Competitive Advantage of Nations, 33). 
je birokracija "zakočena" troši se previše vremena na beskonačne rasprave s državnim tijelima ili ako sudbena vlast ne rješava sporove brzo i nepristrano, tvrtke troše novac i vrijeme za upravljanje na način da time ne doprinose stvaranju vrijednosti za kupca". ${ }^{73}$

U tom smislu konkurentsko vodstvo uočeno na prostoru sjeverozapadne Hrvatske sugerira zaključak da taj prostor posjeduje danas specifična obilježja koje ga u okviru statističke regije kontinentalne Hrvatske diferenciraju i kao specifičan sustav "clustera". Imajući u vidu spoznaju da su suvremene socio-ekonomske karakteristike "clustera" u sjeverozapadnoj Hrvatskoj ${ }^{74}$ utvrđene na području koje se iz povijesnih razloga konstituiralo kao modernizacijsko žarište Hrvatske ${ }^{75}$ razložno je zaključiti da to područje danas posjeduje kapacitet posebnog socio-okolišnog sustava $^{76}$ koji ga u postojećoj administrativnoj fizionomiji Hrvatske i Europe kvalificira kao "pod-regiju". S druge strane, pregled relevantne literature je jasno pokazao da a) postojeća statistička regionalizacija Hrvatske na 2 NUTS 2 regije otežava formuliranje i praćenje regionalnih politika ${ }^{77}$ dok podjela zemlje na NUTS 3 razinu umanjuje, prema Kopriću, ${ }^{78}$ sposobnost nacionalne administracije da razvija svoju ekonomsku i ekološku misiju. Stoga je opravdano, u postojećim okvirima Zakona o regionalnom razvoju, analitički i razvojno promatrati sjeverozapadnu Hrvatsku kao pod-regiju pa je u nastavku korisno objasniti što se podrazumijeva pod konceptom pod-regionalne "elastičnosti" i razloge zbog kojeg je taj koncept od interesa za sjeverozapadnu Hrvatsku.

Elatičnost, zapravo, znači da pod-regija sjeverozapadne Hrvatske može mijenjati svoju veličinu s obzirom na "cluster" u kojem se određena tekuća ili buduća razvojna socio-ekonomska dinamika odvija i/ili planira. Prevedeno na administrativni jezik to znači da na današnjoj NUTS 3 razini, sjeverozapadna Hrvatska može obuhvaćati 3, 4 ili 5 županija ovisno o homogenosti "clustera" koji se želi afirmirati pojedinim mjerama javne politike ili pojedinim projektima i programima namijenjenim europskim fondovima. Preliminarna analiza sadržaja realnosektorskih "clustera" koju je moguće identificirati na području Sjeverozapadne

73 M. E. PORTER, "The Adam Smith Address: Location, Clusters, and the New Microeconomics of Competition". National Association for Business Economics, $39^{\text {th }}$ Annual Meeting of NABE, New Orleans, LA, September 14 - 17, 1997, 1998.b, 10.

74 N. KURNOGA ŽIVADINOVIĆ, n. dj.; L. TIJANIĆ, n. dj.

75 I. ROGIĆ, Tehnika i samostalnost; I. OBADIĆ, n. dj.; S. POLJANEC-BORIĆ, n. dj.

76 D. NIR, Region as a Socio-environmental System. An Introduction to a Systemic Regional Geography.

77 Ž. LOVRINČEVIĆ, Z. MARIĆ, E. RAJH, n. dj.

78 I. KOPRIĆ, "Lokalna samouprava u Hrvatskoj: pokvarena igračka u rukama politike", 1. Forum za javnu upravu, Zaklada Friedrich Ebert i Institut za javnu upravu, Zagreb, 2012, 7. - 28. 
Hrvatske pokazuje da prerađivačka industrija hrane i pića $\left(\right.$ AIK $\left.^{79}\right)$ formira "cluster" koji obuhvaća pet županija sjeverozapadne Hrvatske. Isto vrijedi i za "toplički" cluster $^{80}$ te za onaj kulturno-povijesni (Grad Zagreb, bez vremenske atribucije). S druge strane kožarski, metaloprerađivački i građevinski "clusteri" zasad su čvrsto "ugrađeni" u tri županije (Krapinsko-zagorsku, Varaždinsku i Međimursku) ${ }^{81}$ Isto vrijedi i za vinski „cluster" ponajprije zahvaljujući klimatološkoj homogenosti ove tri županije. Napokon, u jednoj se županiji (Međimurskoj) polagano se revitalizira onaj tekstilni. $^{82}$

$\mathrm{S}$ obzirom na gore navedene uvide, razložno je, u slučaju sjeverozapadne Hrvatske, za europske fondove predlagati elastične pod-regionalne razvojne projekte čija tema ovisi o homogenosti "clustera" koji se određenim projektom optimizira. Ovakav "elastični" pristup omogućava maksimiziranje sinergije u razvoju pod-regionalne konkurentnosti a time i kvalitete života na ovom području, jer nudi istovremeno konkurentsku diferencijaciju sjeverozapadne Hrvatske $u$ kontekstu europske statističke regionalizacije Hrvatske ali i afirmaciju različitih aspekata pod-regionalne heterogenosti unutar pojedinih proizvodnih ili uslužnih "clustera". Također, ovakav pristup omogućava maksimalnu suradnju ove pod-regije sa Zagrebom kao utjecajnom urbanom aglomeracijom kojoj aktualni Zakon o regionalnom razvoju daje specifičan značaj. Ovo je, naime, bitan čimbenik održivog rasta pod-regije sjeverozapadne Hrvatske zbog činjenice da Zagreb u odnosu na ovu pod-regiju predstavlja ogroman i stalan izvor potražnje za sve proizvode koji proizlaze iz aktivnosti podregionalnih "clustera". Napokon ne treba gubiti iz vida činjenicu da je statistička regionalizacija u Hrvatskoj volatilna. U tom smislu pod-regionalna perspektiva za sjeverozapadnu Hrvatsku u okviru postojeće kontinentalne statističke regije može biti koristan za stabiliziranje razvojnog položaja ovog područja te za brzu adaptaciju ovog područja novim modalitetima statističke regionalizacije Hrvatske.

79 AIK je akronim za Agenciju za investicije i konkurentnost; "Agencija za investicije i konkurentnost", Invest in Food and Beverage Industry, Zagreb, 2011.

80 Mirjana POLANČEC, Primjena prirodnih hidrogeokemijskih i izotopnih trasera u istraživanju geotermalnih vodonosnih sustava; Geotehnički fakultet Varaždin, Sveučilište u Zagrebu, 2011.

81 http://www.poslovni.hr/hrvatska/tekstilna-http://www.zara.hr/files/file/pdf/Reg-politika-GH-udzbenik. pdfindustrija-na-koljenima-a-hrvatski-kozari-jaci-nego-ikada-297459 (Pregledano: 25. 5. 2016.); http://m. tportal.hr/biznis/390909/Dragutin-Drk-je-neprikosnoveni-lider-biznisa-u-Varazdinu.html (Pregledano: 25. 5. 2016.).

82 Ibe/VLM, "Međimurski tekstilci zapaženi na pariškom sajmu", Večernji list, 13. ožujka 2013. http:// www.vecernji.hr/sjeverozapadna-hrvatska/medjimurski-tekstilci-zapazeni-na-pariskom-sajmu-523708 (Pregledano 20. 5. 2016.). 


\section{ZAKLJUČAK}

Postoje jasni povijesni i suvremeni razlozi da se prostor sjeverozapadne Hrvatske promatra kao specifična cjelina kako s obzirom na NUTS 2 tako i s obzirom na NUTS 3 razinu regionalno - administrativnog uređenja Republike Hrvatske. Čini se da je, u postojećim okvirima, pod-regionalni status ovog područja, optimalan za praćenje regionalne politike razvoja u okviru u kojem se on oslanja na povlačenje sredstava iz razvojnih fondova Europske Unije. Također, korisno je u tim uvjetima primjenjivati koncept elastične pod-regije jer se time povećava kapacitet pojedinih "clustera" koji postoje u pod-regionalnom okviru a koji su u nekim industrijama veći (prerada hrane i pića) a u nekim manji (kožarstvo, vinarstvo). Povezivanje pod-regionalne perspektive s konceptom "clustera" može imati katalitički učinak na društveni razvoj pod-regije jer potiče razmjernost i umnožavanje ${ }^{83}$ dok s druge strane ojačava pod-regionalnu sinergiju u elastičnim okvirima. Najnovija istraživanja pokazuju da u "clusterima" utemeljenim na nekom od oblika ekonomije doživljaja kojih u podregiji sjeverozapadne Hrvatske ima tri (toplički, vinski i kulturni) mogu značajne koristi izvući iz ranog uključivanja strateškog marketinga u oblikovanje turističke konkurentnosti. ${ }^{84}$ Stoga se čini razložnim dalje istražiti značaj pod-regionalne perspektive za prostor sjeverozapadne Hrvatske jer ona može biti temelj stabilnog razvoja ovog područja u okviru stabilne NUTS 3 administrativne podjele zemlje te volatilnih praksi europske statičke regionalizacije u Republici Hrvatskoj u kojima pod regije mogu prerasti u realne statističke regije..$^{85}$

\section{LITERATURA}

1. "Agencija za investicije i konkurentnost", Invest in Food and Beverage Industry, Zagreb, 2011.

2. Bjørn T. ASHEIM, Arne ISAKSEN, “Location, agglomeration and innovation: Towards regional innovation systems in Norway?", Taylor \& Franicis Online, European Planning Studies, Vol. 5, Issue 3: Globalization, Regional and Local Knowledge Transfer / 2007, 299. - 330.

83 C. M. CHRISTENSEN, H. BAUMANN, R. RUGGLES, T. M. SADTLER, n. dj.

84 Eran KETTER, Yoel MANSFELD, Eli AVRAHAM, "The Role of Marketing in Tourism Planning: Overplay, Underplay or Interplay?", Institut za turizam, Turizam, 64 (2)/2016, 135. - 147.

85 Adriano MILOVAN, “RH se dijeli u nove statističke regije radi lakšeg povlačenja novca iz EU“, Jutarnji list, 14. studenoga 2016., str. 11. 
3. Predrag BEJAKOVIĆ, Ljiljana KALITERNA-LIPOVČAN, Quality of Life in Croatia: Key Findings from National Research, European Foundation for the Improvement of Living and Working Conditions, Dublin, 2007.

4. Jacqueline BEAUJEU-GARNIER, La géographie: méthodes et perspectives, Masson, Paris, 1971.

5. Clayton M. CHRISTENSEN, Heiner BAUMANN, Rudi RUGGLES, Thomas M. SADTLER, "Disruptive Innovation for Social Change", HBSPC, Harvard Business Review, December Issue/2006. http://www.cnid.cl/wp-content/uploads/2015/10/ Disruptive-Innovation-for-Social-Change_2006.pdf (20. 10. 2016.).

6. Paul CLAVAL, Régions, nations, grands espaces, Genin, Paris, 1968.

7. Dajana CVRLJE, Tomislav ĆORIĆ, “Macro \& Micro Aspects of Standard of Living and Quality of Life in a Small Transition Economy: The Case of Croatia", Ekonomski fakultet Sveučilišta u Zagrebu, Working Paper Series, 2/2010, 1. - 12.

8. Grad Zagreb (nepoznato), Regija digitalnih muzeja: Sjeverozapadna Hrvatska, Gradski odjel za strategijsko planiranje, Zagreb.

9. Mario HOLZNER, Amat ADAROV, Luka ŠIKIĆ, “Backwardness, Industrialisation and Economic Development in Europe: The Developmental Delay in Southeastern Europe and the Impact of the European Integration Process Since 1952", The wiiw Balkan Observatory Working Papers 123, 2016., June.

10. Ibe/VLM, "Međimurski tekstilci zapaženi na pariškom sajmu", Večernji list, 13. ožujka 2013. http://www.vecernji.hr/sjeverozapadna-hrvatska/medjimurskitekstilci-zapazeni-na-pariskom-sajmu-523708 (Pregledano 20. 5. 2016.).

11. Eran KETTER, Yoel MANSFELD, Eli AVRAHAM, "The Role of Marketing in Tourism Planning: Overplay, Underplay or Interplay?“, Institut za turizam, Turizam, 64 (2)/2016, 135. - 147.

12. Hrvoje KEKEZ, "Grb Republike Hrvatske: simbol, identitet i tradicija", Most - The Bridge, Glasilo Hrvatske katoličke misije u Londonu, 6/2012, 36. - 46.

13. Zoran KLARIĆ, “Funkcija sjedišta županije i prometne veze kao čimbenici privlačnosti glavnih urbanih središta Hrvatske“, Hrvatsko geografsko društvo - Zadar, Odjel za geografiju, Sveučilište u Zadru, GeoAdria, 20 (1)/2016, 29. - 57.

14. Ivan KOPRIĆ, “Lokalna samouprava u Hrvatskoj: pokvarena igračka u rukama politike", 1. Forum za javnu upravu, Zaklada Friedrich Ebert i Institut za javnu upravu, Zagreb, 2012, 7. - 28.

15. Ivan KOPRIĆ, “Je li moguća regionalizacija Hrvatske? Institucionalna i politička ograničenja“, Fakultet političkih znanosti Sveučilišta u Zagrebu, Političke analize, $5(17) / 2014,9 .-16$. 
16. Nataša KURNOGA ŽIVADINOVIĆ, “Multivarijantna klasifikacija županija Hrvatske", Ekonomski fakultet Zagreb, Zbornik Ekonomskog fakulteta u Zagrebu, $5(1) / 2007,1 .-15$.

17. Željko LOVRINČEVIĆ, Zdravko MARIĆ, Edo RAJH, “Kako optimalno regionalizirati Hrvatsku?“" Hrvatsko društvo ekonomista, Zagreb, Ekonomski pregled, 56 (12)/2005, 1109. - 1160.

18. Damir MAGAŠ, "Koncept teritorijalnog ustroja Jadranske Hrvatske", Hrvatsko geografsko društvo - Zadar, Odjel za geografiju, Sveučilište u Zadru, GeoAdria, $16(2) / 2011,211 .-236$.

19. Damir MAGAŠ, “Jadranska Hrvatska iz perspektive regionalizacije Europske Unije“, Fakultet političkih znanosti Sveučilišta u Zagrebu, Političke analize, 5 (17)/2014, 23. - 29.

20. Pero MALDINI, "Politički i administrativni aspekti regije: regionalizam, regionalizacija i regionalna politika", Sveučilište u Dubrovniku, 1. Zbornik Sveučilišta u Dubrovniku, 1 (1)/2014, 125. - 153.

21. Sanja MALEKOVIĆ, Jakša PULJIZ, “Izazovi novog pristupa upravljanju razvojem na lokalnoj i regionalnoj razini u Hrvatskoj", Nova hrvatska lokalna i regionalna samouprava, Hrvatska akademija znanosti i umjetnosti, ur. Jakša BARBIĆ, Zagreb, 2010., 199. - 222.

22. Adriano MILOVAN, "RH se dijeli u nove statističke regije radi lakšeg povlačenja novca iz EU“, Jutarnji list, 14. studenoga 2016., str. 11.

23. Dov NIR, Region as a Socio-environmental System. An Introduction to a Systemic Regional Geography, Kluwer Academic Publishers, Dordrecht, Boston, New York, 1990.

24. Ivan OBADIĆ, "Međuodnos ljudi i rijeke Drave na području varaždinske Podravine u novom vijeku“, Hrvatska akademija znanosti i umjetnosti, Radovi Zavoda za znanstveni rad Varaždin, 18/2017, 301. - 325.

25. Conor O'DWYER, "Reforming Regional Governance in East Central Europe: Europeanization or Domestic Politics as Usual?", Sage Journals, East European Politics and Societies, 20 (2)/2006, 219. - 253.

26. Mirjana POLANČEC, Primjena prirodnih hidrogeokemijskih i izotopnih trasera $u$ istraživanju geotermalnih vodonosnih sustava; Geotehnički fakultet Varaždin, Sveučilište u Zagrebu, 2011.

27. Saša POLJANEC-BORIĆ, “Razvoj Vukovarsko-srijemske županije u svjetlu socioekonomske tipologije endogenog razvitka u Hrvatskoj", Institut društvenih znanosti Ivo Pilar, Društvena istraživanja, 17 (1-2)/2008, 3. - 26. 
28. Michael E. PORTER, The Competitive Advantage of Nations, The Free Press, New York, 1998.a.

29. Michael E. PORTER, “The Adam Smith Address: Location, Clusters, and the New Microeconomics of Competition". National Association for Business Economics, $39^{\text {th }}$ Annual Meeting of NABE, New Orleans, LA, September 14 - 17, 1997, 1998.b.

30. Robert PUTNAM, "The Prosperous Community", The American Prospect, 4 (13)/1993, 35. - 42.

31. Ivan ROGIĆ, "Hrvatska i njezine regije", Institut društvenih znanosti Ivo Pilar, Društvena istraživanja, 1 (1)/1992, 25. - 34.

32. Ivan ROGIĆ, Tehnika i samostalnost. Hrvatska sveučilišna naklada, Zagreb, 2000.

33. Lela TIJANIĆ, "Regionalna (ne)konkurentnost u Republici Hrvatskoj", Hrvatsko društvo ekonomista, Zagreb, Ekonomski pregled, 61 (7-8)/2010, 419. - 454.

34. Aleksandar TOSKIĆ, Dražen NJEGAČ, "Changes in Political and Territorial Organization and their Impact on Croatia's Urban System and Regional Development", Hrvatsko geografsko društvo, Hrvatski geografski glasnik, 65 (1)/2003, 7. -24 .

35. Zakon o izbornim jedinicama za izbor zastupnika u zastupnički dom Hrvatskog državnog sabora, Narodne Novine br. 116/1999.

36. Zakon o regionalnom razvoju Republike Hrvatske, Narodne Novine br. 147/2014.

\section{Internetski izvori}

1. http://www.poslovni.hr/hrvatska/tekstilna-http://www.zara.hr/files/file/ pdf/Reg-politika-GH-udzbenik.pdfindustrija-na-koljenima-a-hrvatskikozari-jaci-nego-ikada-297459 (Pregledano: 25. 5. 2016.)

2. http://m.tportal.hr/biznis/390909/Dragutin-Drk-je-neprikosnoveni-lider-biznisau-Varazdinu.html (Pregledano: 25. 5. 2016.) 


\section{SAŽETAK \\ SOCIOEKONOMSKI RAZVOJ I KVALITETA ŽIVLJENJA U SJEVEROZAPADNOJ HRVATSKOJ: STATISTIČKA REGIONALIZACIJA KAO OKVIR ZA ELASTIČNU PODREGIJU}

Kvaliteta života je usko povezana s konceptom životnog standarda koji najčešće ovisi

o konkurentnosti. Životni standard se odnosi na fizičke uvjete u kojima ljudi žive, dobra i usluge koje mogu trošiti i resurse kojima imaju pristup. Istraživanja su pokazala da je u Hrvatskoj od 2000. - do 2008. godine ostvaren rast životnog standarda te da je zabilježena relativno visoka vrijednost indikatora općeg i subjektivnog osjećaja sreće. Ono što vrijedi za nacionalnu razinu, vrijedi, mutatis mutandis, za sjeverozapadnu Hrvatsku jer ona posjeduje najveću regionalnu konkurentnost u Republici Hrvatskoj. Prijepori povezani s administrativnom podjelom zemlje na županije i na statističku podjelu zemlje na dvije regije - Kontinentalnu i Jadransku Hrvatsku - razriješeni su u novom Zakonu o regionalnom razvoju iz 2015. godine na način da ne dovode u pitanje županijsku organizacijsku strukturu. Također, spomenuta zakonska rješenja uvode velike urbane aglomeracije kao nove aktere regionalnog razvoja. Na taj način se povećava broj različitih tipova aktera regionalnog razvoja. Zbog olakšavanja praćenja učinaka regionalne politike razvoja preporuča se da se sjeverozapadna Hrvatska, u uvjetima postojeće europske statističke regionalizacije, promatra kao elastična pod-regija.

Ključne riječi: kvaliteta života; sjeverozapadna Hrvatska; konkurentnost; statistička regija; elastična pod-regija.

\section{SUMMARY}

\section{SOCIOECONOMIC DEVELOPMENT AND QUALITY OF LIFE IN NORTHWESTERN CROATIA: STATISTICAL REGIONALIZATION AS A FRAME FOR ELASIC SUB-REGION}

Quality of life is the concept closely related to the concept of standard of living which is, in turn, related to the competitiveness. Standard of living usually relates to physical conditions of life, goods and services that can be consumed and resources that can be accessed. Research has shown that Croatia had a stable growth of standard of living in 2000 2008 periods. Also, relatively high general and subjective happiness has been documented. What is applicable to the national level can be, mutatis mutandis, applied to the northwest Croatia as it features the highest regional competitiveness. The controversy related to the administrative division of country by counties and statistical division of country into two regions - Continental and Adriatic Croatia - has been resolved in the new Law on Regional Development from 2015 which left the county division of country intact. However, the mentioned law established urban agglomerations as new actors of regional development. Thus, the new law created bigger number of different types of actors of regional development. 
In order to facilitate the monitoring of the effects of regional development it is suggested that, within the current statistical regionalization of country, northwest Croatia should be regarded as an elastic sub-region.

Key Words: Quality of life; northwest Croatia; competitiveness; statistical region; elastic sub-region. 